\title{
Antecedents of Conspicuous Consumption in Decision-Making Process Using AHP
}

\author{
Sanjaya Sarathy P \\ Pacific Academy of Higher Education and Research University \\ E-Mail: sanjay_sarathy@yahoo.com
}

\begin{abstract}
The purpose of this research is to determine the antecedents that influence conspicuous consumption in the decision-making process of low-income consumers. The research methods used include a literature review, in-depth interviews, and focus groups. Four interdisciplinary antecedents that influence conspicuous consumption were identified: socio-psychological (societal hierarchy, situational occurrence); brand features (management-controlled, external factor); consumer behavior (product uniqueness, bandwagon); and marketing associates (high involvement, opinion leader). The research techniques were an analytic hierarchy process and an interview questionnaire. Opinions from 200 respondents were collected and analyzed in Mumbai, India. Marketing associates were found to be the most important antecedent, followed by socio-psychological antecedents. Based on these results, it is recommended that researchers, policy makers, and marketing directors share these insights with academic and marketing researchers. Opinion leaders also play a vital role in influencing the decision-makers in conspicuous consumption among lowincome consumers.
\end{abstract}

Keywords: Conspicuous Consumption, AHP, Mumbai

\section{INTRODUCTION}

Conspicuous consumption is a status symbol that satisfies an individual's desire for uniqueness and social membership (Chaudhuri \& Manjumar, 2006). Consumers buy branded products and pay for superior quality to show wealth to their members of social class (Shipman, 2004). In this purchasing event, the consumption may be subtle (O’Cass \& McEwen, 2004).

Ordabayeva and Chandon (2009) suggested that conspicuous consumption is driven by status gains, whereas Charles, Hurst, and Roussanov (2009) argued that due 
to the decreasing marginal return to signaling obtained through conspicuous consumption in the average income of a person's reference group, less conspicuous consumption can be observed among members of wealthier reference groups.

A recent empirical study by Nelissen and Meijers (2012) defines conspicuous consumption in terms of the perceived rewards one expects due to favorable statusdependent treatment in social interactions. Sivanathan and Pettit's (2010) study confirms that individuals have a high degree of sensitivity toward their social status. Conspicuous consumption is considered as an expensive mode of signaling, but a profitable social strategy adopted by wealthier households.

Human capital is observable and correlated with income. A signaling equilibrium in which poor individuals tend to spend a large fraction of their income on conspicuous consumption can then emerge (Moav \& Neeman, 2012). In conspicuous consumption, personality traits drive consumers' materialistic behaviour (Chacko \& Ramanathan, 2015). Conspicuous consumption in clothing and its relationship to public self-consciousness, materialism, and self-esteem are associated with the expensive dimensions in young professionals (Abbie \& Miguel, 2016).

It is therefore very important to study conspicuous consumption in the decisionmaking process of low-income consumers.

\section{LITERATURE REVIEW}

\section{Conspicuous Consumption}

The term “conspicuous consumption” was introduced by Veblen (1899), who argued that individuals often consume attention-seeking goods and services to signal their wealth and thereby elevate their social status.

For conspicuous products, consumers' need for uniqueness prevails. However, consumers value the product less as more people come to own it, thus exhibiting negative consumption externalities. Examples of conspicuous products include certain types of jewelry, perfumes, designer handbags, watches, high-end cars, and collectibles; exclusivity is intrinsic to the value of the product. Duesenberry (1967) originated the idea of the bandwagon effect. Chao and Schor's (1998) study of cosmetics found that conspicuous cosmetics are less differentiated. The younger professional relates themselves to expensive clothes rather than fashionable or designer clothes. (Abbie \& Miguel, 2016).

\section{Low-Income Consumers}

The low income consumers has two category - Relatively low income consumer, in which they earn less income, but manages basic needs and Absolute low income 
consumer, in which they don't earn sufficient income even for basic needs. We have assumed relatively low income consumers for our research. They fall below the poverty line, “in relative poverty," meaning "earning low-income consumers" (relative low-income consumers) and "in absolute poverty" meaning "experience difficulty for even basic needs” (absolute low-income consumers).

While absolute low-income consumers are vulnerable to rising oil and food prices, natural disasters, and economic crises, relatively low-income consumers are clustered slightly above the poverty line and are therefore also vulnerable to natural disasters and economic crises. The extent to which low-income consumers would spend on conspicuous consumption depends on several factors and motivation, for conspicuous consumption may reflect a need for satisfaction or equal status with people who are well-off. Specially, in South Asia, low-income consumers try to imitate the consumption pattern of people who are socially well-established.

Van Kempen (2003) demonstrated that in Bolivia, low-income consumers are not only willing to pay a premium on designer goods but also sometimes prioritize conspicuous goods over necessities. In India, we encounter the quest for social status on the wedding market, where weddings can cost as much as six times the annual household income (Anderson, 2003). Bloch, Rao, and Desai (2004) indicated that even low-income consumers experience stress because of the highly conspicuous nature of ritual expenditures in India, specifically on wedding celebrations and dowries, to gain social status.

\section{Analytic Hierarchy Process}

The analytic hierarchy process (AHP) is a structured technique for organizing and analyzing complex decisions, based on mathematics and psychology. It was developed at the Wharton School of Business by Thomas Saaty $(1980,1994)$ and has been extensively studied and refined. It has particular application in group decision making and is used around the world in a wide variety of decision situations. Rather than prescribing a "correct" decision, the AHP helps decision makers find one that best suits their goal and their understanding of the problem. Zahedi (1986) provided an extensive list of references on the AHP methodology and its applications.

Marsh, Moran, Nakui, and Hoffherr (1991) designed a comprehensive and rational framework for structuring a decision problem, and specific method of decision The goal, objective and criteria are the three logical steps involved in the famous 'Marsh AHP' model, which is practiced even today. Marsh's AHP had three steps: Goal, Objectives or Criteria, and Attributes or Alternatives. AHP enables decision-makers to derive ratio scale priorities or weights rather than arbitrarily 
assigning them. In so doing, AHP supports decision-makers by enabling them to structure complexity and exercise judgment while incorporating both objective and subjective considerations into the decision process (Zopounidis \& Doumpos, 2006b). AHP has the following advantages in group making (Dyer \& Forman, 1992):

- All values, individual and/or group, tangible and/or intangible, are contained in group decision process.

- The discussion focuses on the goal instead of options.

- The discussion media in which all factors are considered is established.

- The discussion continues until consensus is reached.

The AHP breaks down a complex and unstructured situation into its component parts, and then rearranges those parts (or variables) into a hierarchical order. It is ideally suited to resolve problems that arise when multiple criteria are used in performance evaluation. For example, the pair-wise comparisons for measure(s) priority can be done using a ratio scale. The AHP has been applied in a variety of decision-making environments (Golden, Wasil, \& Harker, 1989). This study is based on group decision-making. In addition to final preference weights, the AHP permits calculation of a value called the consistency index. This index measures transitivity of preference for the person doing pair-wise comparisons (Sinuany-Stern, 1988).

To illustrate the meaning of transitivity of preference, if a person prefers choice $\mathrm{A}$ to $\mathrm{B}$, and $\mathrm{B}$ to $\mathrm{C}$, then does he or she consistently prefer $\mathrm{A}$ to $\mathrm{C}$ ? This index offers a useful check, because the AHP method does not inherently prevent the expression of intransitivity of preferences when ratings are being performed. The AHP consistency index compares a person's informed preference ratings to those generated by a random preference expression process. An arbitrary but tolerable level of inconsistent preference scoring with AHP is less than or equal to 0.1 (Sinuany-Stern, 1988). A consistency ratio (CR) is computed for each comparison matrix. In an interactive application of AHP, a matrix classified as being inconsistent (CR > 0.1) was given back to decision-making for modification until it fulfills the consistency condition. All of them were less than 0.1 (Mirkazemi, Hemmatinesgad, Gholizadeh, \& Ramazanian, 2009). For determining weight of every alternative, arithmetic means were used based on formula 1 :

$$
r_{i j}=a_{i j} / \sum_{i=1}^{n} a_{i j} \quad \mathrm{~J}=1,2,3, \ldots \ldots . . \mathrm{m}
$$


The vectors of the arithmetic means of the coefficients of importance were rescaled in the manner that their sum equaled 1 . Then the symphonic means were calculated based on formula 2:

$$
W_{i}=\sum_{i=1}^{n} r_{i j} / \mathrm{n} \quad \mathrm{J}=1,2,3, \ldots \ldots . \mathrm{m} \quad \text { Formula } 2
$$

\section{ANTECEDENTS}

Identifying the priorities of antecedents that influence the conspicuous consumption is just as important as other decisions. The AHP can also be used to rank the importance of various alternatives. In this study, the application of the AHP technique helps identifying what are the antecedents that influence the conspicuous consumption and their relative importance.

Few studies have been conducted on the importance and ranking of inter discipline antecedents that influence conspicuous consumption. Based on the viewpoint of the decision-maker, it is important to examine conspicuous consumption more closely. The literature review of four antecedents/variables is studied in-depth in this research.

\section{Societal Hierarchy}

Several researchers including Wong and Ahuvia (1998) and O'Cass and Frost (2002) have suggested that factors such as prestige and success symbolism, wealth and achievement indication, and image and status enhancement as intangible factors relate to the societal hierarchy involved in conspicuous consumption. This is mostly due to the theoretical rather than empirical nature of the debate over conspicuous consumption (Mason, 2002). Nagel and Holden (2002) argue that as the value of a conspicuous product increases, an individual's standing in the social hierarchy rises (Fitzmaurice \& Comegys, 2006). However, Clark, Zboja, and Goldsmith (2007) suggest that little is known about societal hierarchy factors in conspicuous consumption. Thus, in a societal hierarchy, conspicuous consumption may increase.

\section{Situational Occasion}

Researchers have not directly examined the role of situations in conspicuous consumption (Graeff, 1997). Most studies of the impact of situations have used hypothetical scenarios (Quester \& Smart, 1998). According to Solomon, Bamossy, and Askegaard (2002), situations associated with conspicuous consumption are based on the characteristics of the person and the product, and its effects can be behavioral and perceptual. Consumers seldom operate in a social vacuum; rather, they 
continuously compare themselves with significant others when consuming conspicuous product and situations. Social occasions such as weddings, or cultural and religious festivals are perfect venues to elevate an individual's status (Clark et al., 2007). Therefore, we can conclude that conspicuous consumption is situational.

\section{Uniqueness}

The "snob effect" takes into consideration the consumer's personal and emotional desires when purchasing or consuming branded conspicuous products, but it also influences and is influenced by the behavior of others (Mason, 1995). Research reveals that a perceived limited supply of products actually improves consumers' evaluation of a product (Amaldoss \& Jain, 2005).

Development drives the need for uniqueness, encouraging consumers to interpret products differently, add meaning to them, and invent newer ways of self-expression and communication (Douglas \& Isherwood, 1996). These arguments are consistent with researchers' "observations of consumers," expressed as "need for uniqueness or distinct conspicuous products” (Tian, Bearden, \& Hunter, 2001). Thus, we can conclude that the uniqueness of the products is distinct from the need for conspicuous consumption.

\section{Bandwagon}

The bandwagon occurs due to an increase in the consumption of the commodity by others (Leibenstein, 1950). High demand of restaurants reflects the consumer's desire, leading to an increase in attractiveness. Thus, consumer are known for herd behavior and desire for social status (Becker, 1991). For instance, consumers' purchase a conspicuous product in order to be associated with a particular group (Berger \& Ward, 2010; Escalas \& Bettman, 2005). The consumer who jumps on the bandwagon is encouraged by self-concept to affiliate with reference groups and to achieve status or rank within a social community (Kastanakis \& Balabanis, 2012). Thus, the bandwagon effect influences the purchase of conspicuous products.

\section{Brand Associates}

Branding in conspicuous consumption should be viewed from the perspectives of internally and externally controlled brand features (Erdem \& Swait, 1998). Internally controlled brand features are those under the control of management and can be developed and managed through packaging, distribution and fine-tuned promotion (O’Cass \& Frost, 2002). Market-controlled features are beyond the control of management (Hirschman \& Holbrook, 1982). 
Researchers have suggested management-controlled brand features such as brand familiarity, brand symbolism (Eastman, Goldsmith, \& Flynn, 1999; Wong \& Ahuvia, 1998), and brand awareness (Aaker, 1999). Market-controlled feature-based research has included the impact of affective response (Agrawal \& Malhotra, 2005), selfconcept and congruity (O’Cass \& Frost, 2002), and country-of-origin effects (Ahmed, Johnson, Ling, Fang, \& Hui, 2002).

A study by O'Cass and Frost (2002) examined brand associations in conspicuous consumption tendencies. However, there is little empirical evidence on the impact of branding-related features on conspicuous consumption (O’Cass \& Frost, 2002; Shukla, 2008). Therefore, it will be interesting to observe the effects of both management- and market-controlled branding features on conspicuous consumption for low-income consumers.

Thus, we can conclude that conspicuous consumption is significantly influenced by internal brand features such as product attributes, packaging, and points of distribution and by external brand features such as self-concept, congruity, and country-of-origin effects.

\section{High-Involvement Products}

Horiuchi (1984) observed that it made intuitive sense to classify luxury products as high involvement rather than low involvement. Furthermore, the purchase of such products may improve the status for people of all social classes (Cuneo, 1996). Generally, luxury items are high-involvement products that are purchased to gain status (Prendergast \& Wong, 2003) and are related to conspicuous consumption (Wong, 1997). Opinion leaders influence the consumers' decision-making and are significant in disseminating information, specifically about high-involvement purchases (Sarathy, 2013).

The imported high-complexity product is related to high social status (Bow \& Ford, 1993) and conspicuous consumption (Marcoux, Filiatrault, \& Cheron, 1997). Motivated by a desire to impress others with their ability to pay a premium for prestige products, even low-income consumers are inspired by social factors (Wang, Siu, \& Hui, 2004). These consumers may try to improve their social status by purchasing high-involvement products such as electronic devices.

The purchasing of high-involvement fashion products falls into the category of conspicuous consumption and it may help improve the social status for people of all economic classes (Souiden \& Pons, 2010). Thus, we can conclude that for low-income consumers, conspicuous consumption is significant for high-involvement products such as durables and new devices. 


\section{Opinion Leaders}

Many consumers rely on opinion leaders when purchasing conspicuous or luxury products (Summers, 1970). Opinion leaders' involvement was a significant predictor for conspicuous sports products (Bloch, Black, \& Lichtenstein, 1990). Conspicuous fashion products were related to opinion leadership in the fashion world. Opinion leaders have social involvement and product knowledge, by influencing the consumer in housing purchase decisions (Sarathy, 2011).

Peer pressure and opinion leaders are often the primary influential factors of purchasing decisions of conspicuous product. Opinion leaders seek the acceptance of others and are especially motivated to enhance their social status (Rose, 2010). Thus, we can conclude that conspicuous consumption for low-income consumers is significantly impacted by bellwethers or opinion leaders.

\section{METHODLOGY}

The antecedents of conspicuous consumption have been well established through literature review. Furthermore, this study consulted expert groups twice to validate the attributes of four objective antecedents of conspicuous consumption in Mumbai, India. The AHP framework contains three structured levels: goal level, objective or criteria level, and attribute or alternative level. The goal level refers to conspicuous consumption of low-income consumers in Mumbai, India. The objective level consists of four antecedents: socio-psychological, brand features, consumer behavior, and marketing associates. Finally, the attribute level includes societal hierarchy, situational occurrences, product uniqueness, management-controlled brand features, externally controlled brand features, high-involvement products, and opinion leaders. The AHPmodel questionnaire research questionnaire was prepared based on these attributes.

\section{Sample}

The AHP questionnaires were administered to 200 low-income workers, who earn less than the basic salary (i.e., Rs.15, 000 per month) as per Indian Pay Commissions in Mumbai. The respondents were cleaners, office assistants, peons, and drivers. Most of the samples were collected in person and some by postal as well as by email. The deadline for data collection was four months. The sampling procedure resulted in response rate of $68 \%$ for both email and in person and is considered to be a strong indicator. Extreme care was taken to ensure data quality. 


\section{FINDINGS AND DISCUSSION}

The marketing associates in objective level is highest, followed by sociopsychological, brand features, and consumer behavior (see Table 1 and Figure 1).

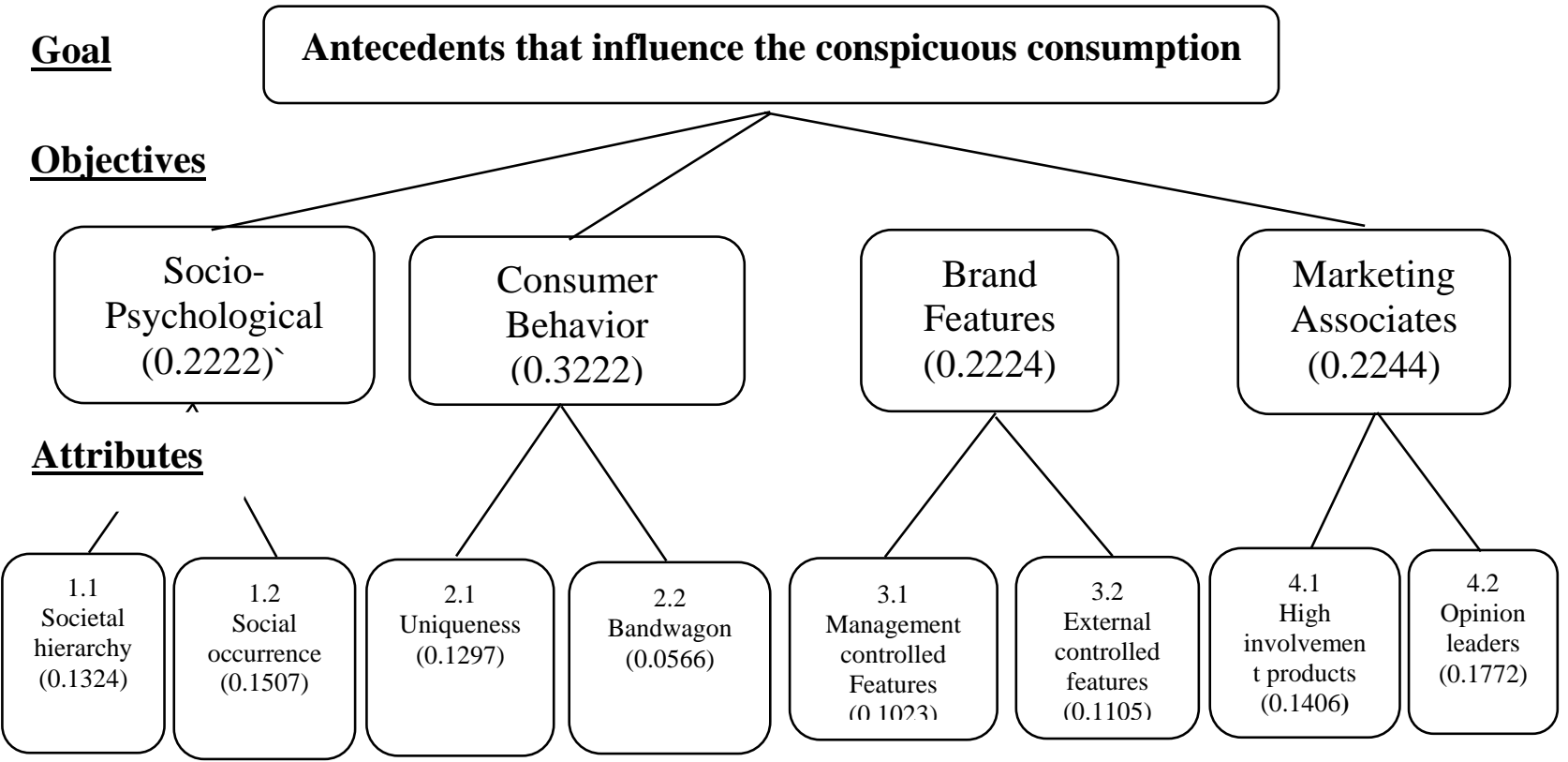

Figure 1 The Weight Ratios of Different Levels of All Antecedents that Influence The Conspicuous Consumption in Decision Making Process.

Table 1 Weight Ratios of Objective Level

\begin{tabular}{ccc}
\hline Antecedents & Weight & Order \\
\hline Socio-psychological & 0.2831 & 2 \\
\hline Consumer behavior & 0.1863 & 4 \\
\hline Brand features & 0.2128 & 3 \\
\hline Marketing associates & 0.3178 & 1 \\
\hline
\end{tabular}

Source: Author's own.

In the conspicuous consumption process, we found that social gains are influential. The social hierarchy made the smallest contribution to the decisionmaking process, as shown in Table 2. 
Table 2 Ranked Results of Pair-Wise Comparison for the Importance of SocioPsychological Antecedents

\begin{tabular}{cccc}
\hline Socio-psychological antecedents & Priority & $\begin{array}{c}\text { Priority } \\
\text { weighted }\end{array}$ & Rank \\
\hline Societal hierarchy & 0.47 & 0.1324 & 2 \\
\hline Social occurrences & 0.53 & 0.1507 & 1 \\
\hline
\end{tabular}

Source: Author's own.

Uniqueness is the main contributor among consumer behavior antecedents, as shown in Table 3.

Table 3 Ranked Results of Pair-Wise Comparison for the Importance of ConsumerBehaviors’ Antecedents

\begin{tabular}{cccc}
\hline $\begin{array}{c}\text { Consumer behaviors' } \\
\text { antecedents }\end{array}$ & Priority & Priority weighted & Rank \\
\hline Uniqueness & 0.70 & 0.1297 & 1 \\
\hline Bandwagon & 0.30 & 0.0566 & 2 \\
\hline
\end{tabular}

Source: Author's own.

Management-controlled features make a slightly larger contributor than external features, as shown in Table 4.

Table 4 Ranked Results of Pair-Wise Comparison for the Importance of Brand Features’ Antecedents

\begin{tabular}{cccc}
\hline Brand features' antecedents & Priority & Priority weighted & Rank \\
\hline Management-controlled & 0.48 & 0.1023 & 2 \\
\hline External features & 0.52 & 0.1105 & 1 \\
\hline
\end{tabular}

Source: Author's own.

Here, the opinion leader is the main contributor followed by high-involvement products as shown in Table 5.

Table 5 Ranked Results of Pair-Wise Comparisons for the Importance of Marketing Associates’ Antecedents

\begin{tabular}{cccc}
\hline Marketing associates' antecedents & Priority & Priority weighted & Rank \\
\hline High-involvement products & 0.44 & 0.1406 & 2 \\
\hline Opinion leaders & 0.56 & 0.1772 & 1 \\
\hline
\end{tabular}

Source: Author's own. 


\section{CONCLUSION}

According to the result provided through AHP, marketing associates' antecedents at objective level and opinion leader at attribute level are the highest. Note that social gains' attributes were the second-largest contributors to conspicuous consumption. Marketing researchers should explore the role of opinion leaders in driving the conspicuous consumption of Mumbai's low-income consumers. Academic researchers should look into opinion leaders in studies of low-income consumers' conspicuous consumption.

\section{RECOMMENDATIONS AND FUTURE FINDING}

The key antecedents in the conspicuous consumption of low-income consumers in Mumbai, India, are opinion leaders and social gains. It is, therefore, suggested that researchers study the ways in which opinion leaders and social gains affect the conspicuous consumption in low-income consumers. Low-income consumers should be compared to high-income consumers. Future studies should also compare the antecedents of conspicuous consumption in other cities in India to other developing countries.

\section{ACKNOWLEDGEMENTS}

This paper has become possible because of the constant support, encouragement given by Dr. Nitin Manohar Joshi and my professors in Pacific Academy of Higher Education and Research University, colleagues, and family members.

\section{REFERENCES}

Aaker, J. (1999). The malleable self: The role of self-expression in persuasion. Journal of Marketing Research, 36, 45-57. http://dx.doi.org/10.2307/3151914

Abbie, L., \& Miguel. M. (2016). Young professionals' conspicuous consumption of clothing. Journal of Fashion of Marketing and Management, 20, 138-156.

Agrawal, J., \& Malhotra, N. K. (2005). An integrated model of attitude and affect: Theoretical foundation and an empirical investigation. Journal of Business Research, 58(4), 483-493. http://dx.doi.org/10.1016/S0148-2963(03)00138-3

Ahmed, Z., Johnson, J., Ling, C. P., Fang, T. W., \& Hui, A. K. (2002). Country-oforigin and brand effects on consumers evaluations of cruise lines. International Marketing Review, 19(3), 279-302. http://dx.doi.org/10.1108/02651330210430703 
Amaldoss, W, \& Jain, S. (2005). Conspicuous consumption and sophisticated thinking. Management Science, 51(10), 1449-1466. http://dx.doi.org/10.1287/mnsc.1050.0399

Anderson, S. (2003). Why dowry payments declined with modernization in Europe but are rising in India. Journal of Political Economy, 111, 269-310. http://dx.doi.org/10.1086/367679

Berger, J., \& Ward, M. (2010). Subtle signals of inconspicuous consumption. Journal of Consumer Research, 37(4), 555-569. http://dx.doi.org/10.1086/655445 http://dx.doi.org/10.1086/655445

Bloch, F., Rao, V., \& Desai, S. (2004). Wedding celebrations as conspicuous consumption: Signaling social status in rural India. Journal of Human Resources, 39, 675-695. http://dx.doi.org/10.2307/3558992

Bloch, P. H., Black, W. C., \& Lichtenstein, D. (1990). Involvement with the equipment component of sport: Links to recreational commitment. Leisure Sciences, 11(3), 187-200. http://dx.doi.org/10.1080/01490408909512219

Becker G. S. (1991). A note on restaurant pricing and other example of social influences on price. Journal of Political Economy, 99(5), 1109-1116. http://dx.doi.org/10.1086/261791

Bow, J., \& Ford, M. (1993). Indonesia and China: The retail of two cities. Asian Business, 29(10), 12-14.

Chacko, P. S., \& Ramanathan, H. N. (2015). Materialism and conspicuous consumption-The extend matters. International Journal of Emerging Research in Management \& Technology, 4(5), 381-387.

Chao, A., \& Schor, J. (1998). Empirical tests of status consumption: Evidence from women's cosmetics. Journal of Economic Psychology, 19, 107-131. http://dx.doi.org/10.1016/S0167-4870(97)00038-X

Charles, K. K., Hurst, E., \& Roussanov, N. (2009). Conspicuous consumption and race. Quarterly Journal of Economics, 124, 425-467. http://dx.doi.org/10.1162/qjec.2009.124.2.425

Chaudhuri, H., \& Manjumar, M. (2006). Of diamonds and desires: Understanding conspicuous consumption from a contemporary marketing perspective. Academy of Marketing Review, 11.

Clark, R. A., Zboja, J. J., \& Goldsmith, R. E. (2007). Status consumption and rolerelaxed consumption: A tale of two retail consumers. Journal of Retailing and Consumer, 14(1), 45-59. http://dx.doi.org/10.1016/j.jretconser.2006.03.003

Cuneo, A. Z. (1996). Luxury goods seeing return of retail growth. Advertising Age, 7(49), 3-53. 
Douglas, M., \& Isherwood, B. (1996). The world of goods: Towards anthropology of consumption. London, England: Routledge.

Duesenberry, J. S. (1967). Income, savings, and the theory of consumer behavior. New York, NY: Oxford University Press.

Dyer, R. F., \& Forman, E. H. (1992). Group decision support with analytic hierarchy process. Decision Support Systems, 8, 1, 99-124. http://dx.doi.org/10.1016/01679236(92)90003-8

Eastman, J. K., Goldsmith, R. E., \& Flynn, L. R. (1999). Status consumption in consumer behavior: Scale development and validation. Journal of Marketing Theory and Practice, 7, 41-52. http://dx.doi.org/10.1080/10696679.1999.11501839

Erdem, T., \& Swait, J. (1998). Brand equity as a signaling phenomenon. Journal of Consumer Psychology, $7(2)$, 131-157. http://dx.doi.org/10.1207/s15327663jcp0702_02

Escalas, J. E., \& Bettman, J. R. (2005). Self-construal, reference groups, and brand meaning. Journal of Consumer Research, 32(3), 378-389. http://dx.doi.org/10.1086/497549

Fitzmaurice, J., \&Comegys, C. (2006). Materialism and social consumption. Journal of Marketing Theory and Practice, 14(4), 287-299. http://dx.doi.org/10.2753/MTP1069-6679140403

Giacobbe, A. (2009). Luxury prices: To cut or not to cut? CNN Money.

Golden, B. L., Wasil, E. A., \& Harker, P. T. (1989). The analytic hierarchy process. New York, NY: Springler-Verlag. http://dx.doi.org/10.1007/978-3-642-50244-6

Graeff, T. R. (1997). Consumption situations and the effects of brand image on consumers’ brand evaluations. Psychology \& Marketing, 14(1), 49-70.

Hirschman, E. C., \& Holbrook, M. B. (1982). Hedonic consumption: Emerging concepts, methods and propositions. Journal of Marketing, 46, 92-101. http://dx.doi.org/10.2307/1251707

Horiuchi, Y. (1984). A systems anomaly: Consumer decision-making process for luxury goods. Doctoral Dissertation, University of Pennsylvania.

Kastanakis, M. N., \& Balabanis, G. (2012). Between the mass and the class: Antecedents of the bandwagon luxury consumption behavior. Journal of Business Research, 65(10), 1399-1407. http://dx.doi.org/10.1016/j.jbusres.2011.10.005

Leibenstein, H (1950). Bandwagon, Snob, and Veblen effects in the theory of consumer's demand. Quarterly Journal of Economics, 64(2), 183-207. 
Marcoux, J. S., Filiatrault, P., \& Cheron, E. (1997). The attitudes underlying preferences of young urban educated Polish consumers towards products made in Western countries. Journal of International Consumer Marketing, 9(4), 5-29. http://dx.doi.org/10.1300/J046v09n04_02

Marsh, S., Moran, J. V., Nakui, S., \& Hoffherr, G. (1991). Facilitating and training in quality function deployment. Methuen, MA: GOAL/QPC.

Mason, R. S. (1995). Interpersonal effects on consumer demand in economic theory and marketing thought. Journal of Economic Issues, 29, 871-882.

Mason, R. (2002). Conspicuous consumption in economic theory and thought. In: E. Fullbrook (Ed.), Inter subjectivity in economics: Agents and structures (pp. 85104). London, England: Routledge. http://dx.doi.org/10.4324/9780203116661.ch6

Mirkazemi, S. A., Hemmatinesgad, M. A., Gholizadeh, M. H., \& Ramazanian, M. R. (2009). Application of the analytic hierarchy process for the performance evaluation criteria of sport offices in universities. Brazilian Journal of Biomotricity, 3(4), 390-398.

Moav, O., \& Neeman, Z. (2012). Saving rates and poverty: The role of conspicuous consumption and human capital. The Economic Journal, 122(563), 933-956. http://dx.doi.org/10.1111/j.1468-0297.2012.02516.x

Nagel, T., \& Holdon, R. (2002). The strategy and tactics of pricing. Upper Saddle River, NJ: Prentice-Hall.

Nelissen, R. M. A., \& Meijers, M. H. C. (2012). Social benefits of luxury brands as costly signals of wealth and status. Evolution and Human Behavior, 32(5), 343355. http://dx.doi.org/10.1016/j.evolhumbehav.2010.12.002

O’Cass, A., \& Frost, H. (2002). Status brands: Examining the effects of non-productrelated brand associations on status and conspicuous consumption, Journal of Product \& Brand Management, 11(2), 67-88.

O’Cass, A., \& McEwen, H. (2004). Exploring consumer's status and conspicuous consumption. Journal of Consumer Behavior, 4(1), 25-39.

Ordabayeva, N., \& Chandon P. (2009). Effects of the density of status distribution on conspicuous and inconspicuous consumption by low-status consumers. Advances in Consumer Research, 36, 13-14.

Prendergast, G., \& Wong, C. (2003). Parental influence on the purchase of luxury brands of infant apparel: An exploratory study in Hong Kong. Journal of Consumer Marketing, 20(2), 157-169. http://dx.doi.org/10.1108/07363760310464613 
Quester, P.G. and J. Smart (1998). The influence of consumption situation and product involvement over consumers' use of product attribute, Journal of Consumer Marketing, 15 (3), 220-38.

Rose, J. (2010). The branding of states: The uneasy marriage of marketing to politics. Journal of Political Science, 9(4), 254-275. http://dx.doi.org/10.1080/15377857.2010.520238

Saaty, T. L. (1980). The analytic hierarchy process. New York, NY: McGraw-Hill.

Saaty, T. (1994). How to make a decision: The analytic hierarchy process. Interfaces, 24(6), 9-26. http://dx.doi.org/10.1287/inte.24.6.19

Sarathy, S. (2011). Opinion leaders in real estate markets. International Real Estate Review, 14(3), 354-373.

Sarathy, S. (2011). Organizational innovations in the real-estate industry using AHP. International Journal of Organizational Innovation, 4(1), 5-26.

Sarathy, S. (2013). TQM practice in real-estate industry using AHP. International Journal of Methodology, 47(4), 2049-2063. http://dx.doi.org/10.1007/s11135011-9641-8

Sarathy, S. (2013). The role of opinion leaders in high-involvement purchases: An empirical investigation. South Asian Journal of Management, 20(2), 127-145.

Shipman, A. (2004). Lauding the leisure class: Symbolic content and conspicuous consumption. Review of Social Economy, 62(3), 277-289. http://dx.doi.org/10.1080/0034676042000253909

Shukla, P. (2008). Conspicuous consumption among middle age consumers: Psychological and brand antecedents. Journal of Product \& Brand Management, 17(1), 25-36. http://dx.doi.org/10.1108/10610420810856495

Sinuany-Stern, Z. (1988). Ranking of sports teams via the AHP. Journal of the Operational Research Society, 39, 661-667. http://dx.doi.org/10.2307/2582188

Sivanathan, N. \& Pettit, N. C. (2010). Protecting the self through consumption: Status goods as affirmation commodities, Journal of Experimental Social Psychology, 46(3): 564-570. http://dx.doi.org/10.1016/j.jesp.2010.01.006

Solomon, M. R., Bamossy, G., \& Askegaard, S. (2002). Consumer behavior: A European perspective. 2nd ed. Harlow: Pearson.

Souiden, N., \& Pons, F. (2010). Product recall crisis management: the impact on manufacturer's image, consumer loyalty and purchase intention, Journal of Product $\quad \& \quad$ Brand $\quad$ Management, 106-114. http://dx.doi.org/10.1108/10610420910949004

Summers, J. (1970), The identity of women's clothing fashion opinion leaders,Journal of Marketing Research, 7 (May), 178-185. 
Tian, K., Bearden, W., \& Hunter, G. (2001). Consumers’ need for uniqueness: scale development and validation. Journal of Consumer Research, 28(1), 50-66.

Van Kempen, L. (2003). Fooling the eye of the beholder: Deceptive status signaling among the low income consumers in developing countries. Journal of International Development, 15, 157-177.

Veblen, T. (1899). The theory of the leisure class. New York, NY: Macmillan Company.

Wang, C.-L., Siu, N., \& Hui, A. (2004). Consumer decision-making styles on domestic and imported rand clothing. European Journal of Marketing, 38(1/2), 239-252.

Wong, N. Y. C. (1997). Suppose you own the world and no one knows? Conspicuous consumption, materialism and sell, Advances in Consumer Research, 24, 197203.

Wong, N. Y., \& Ahuvia, A. C. (1998). Personal taste and family face: luxury consumption in Confucian and Western societies, Psychology \& Marketing, 15(5), 423-441. http://dx.doi.org/10.1002/(SICI)15206793(199808)15:5\%3C423::AID-MAR2\%3E3.0.CO;2-9

Zahedi, F. (1986). The analytic hierarchy process—A survey of the method and it's applications. Interfaces, 16(4), 96-104.

Zopounidis, C., \& Doumpos, M. (2000b). Intelligent decision aiding systems based on multiple criteria for financial engineering. Dordrecht: Kluwer Academic Publishers. http://dx.doi.org/10.1007/978-1-4615-4663-4 